\title{
The Problem of the Representation of Women Authors in Slovenian Secondary School Literature Textbooks
}

\author{
By Zoran Božič*
}

\begin{abstract}
This paper is based on empirical research on the share of women authors in Slovenian secondary school literature textbooks between 1850 and 2000. The highest share (about 15\%) of women authors was achieved after the Second World War and in contemporary textbooks. However, this share occurred in only one of three competing books, one which offers a considerably larger selection of authors than that required by the curriculum. The research showed that the share of women authors depends on the scope of the approach: the fewer authors that are included, the smaller is the likelihood of women authors being represented. With a very strict selection of nationally representative authors, the female gender is not represented at all. The gender of the selector(s) may influence the inclusion of women authors, but not necessarily: a textbook's editor may be a woman, yet still fail to include a single woman author. A comparison between textbooks and literary-historical selections shows that women authors in textbooks are less represented (due to limitations of the scope as determined by the included literary texts), and the selection criteria may also differ.
\end{abstract}

Keywords: Canonization, Didactics, Women authors, Literary history, Slovenian secondary school textbooks

\section{Introduction}

Probably no one doubts any longer that in several thousand years of European history, women in public were a strongly neglected gender until the second half of the $20^{\text {th }}$ century, which was undeniably reflected in their opportunities for literary creation and gaining recognition. Although many men (and women as well) claim that the highly unequal representation of women authors in school curricula and literary textbooks is primarily a consequence of a lower artistic value of their literary works, the fact that an authors' gender matters in the process of selection and canonization cannot be denied.

Even today so-called woman's writing is studied predominantly by female researchers: the male gender finds researching, evaluating and teaching the literature of women authors largely uninteresting or even inferior. The interview the journalist Vesna Milek had with Jennifer Clement, the first woman president of PEN, an international association of writers (Milek 2016) is quite telling. In it the Mexican woman poet and author, a recipient of many awards observes that "the most influential magazines in the English-speaking world, such as The New York Times, The Atlantic Monthly, The Sunday Times, The Nation, The New Yorker, etc. publish almost no book reviews of women authors" and that "almost all books by women authors are reviewed by female and not by male reviewers", which means that "everything remains in some way ghettoized; as if the editors would not give a chance to a reviewer to be able to review a book by a woman author and compare it with a book by a male author." There is a similar situation regarding

\footnotetext{
* Assistant Professor, Faculty of Humanities, University in Nova Gorica, Slovenia.
} 
literary awards: "the book which will never receive an award is a book written by a woman and dealing with women, particularly young ones".

Even the role of women two thousand years ago is researched predominantly by women scholars, as demonstrated by this year's excellent compendium of one thousand pages covering the role of women in antiquity in the Mediterranean space, from Mesopotamia to Carthage. In the systematic study entitled Women in Antiquity: Real Women Across the Ancient World, edited by Stephanie Lynn Budin and Jean MacIntosh Turfa (2016), only 15 out of 74 contributions were submitted by male researchers. A similar proportion is found on the websites dedicated to exchanging freely accessible scientific texts: on the American website Academia.edu with its 42 million registered researchers: the research area "world literatures" has 15 thousand followers, while the field of "teaching gender" only four.

\section{Methodology}

A study on the occurrence of women authors in Slovenian secondary school literature textbooks was carried out with the purpose of establishing the actual state of affairs, investigating the factors instrumental in determining the ratio between genders, and enabling international comparisons. A descriptive comparison between Anglo-American and Slovenian women authors is followed by a quantitative analysis of the general share of women authors in secondary school literature textbooks in terms of the number of appearances and the number of selected literary texts. This is followed by a quantitative demonstration of women authors' classification in reference to the ratio of the realized inclusions out of all possible inclusions and a comparison with men in reference to their age at the time of their inclusion in the literature textbook. The analytical method is then used to ascertain to what degree the share of women authors depended on the scope of the textbook, what the influence of the textbook editor's/editors' gender was, and which social and political changes have an impact on an increased share of women authors.

\section{A Comparison of the Occurrence of Women Authors and the Research of their Literary Works between the Anglo-American Region and Slovenia}

If we take the noble slogans of the French Revolution to also include the right of women to be equally valued and to have equal rights, then we find that the last 200 years have meant a gradual crumbling of the patriarchal social system. This is also visible in the field of literature and literary studies; however, this is yet another example of Slovenia's traditional lagging behind the developed world. ${ }^{1}$

\footnotetext{
${ }^{1}$ For example, at the end of the $18^{\text {th }}$ century, Germany had more than 10,000 professional writers, while the first Slovenian professional writer was Ivan Cankar (1876-1918).
} 
In Great Britain, women authors started emerging as early as during the Enlightenment after 1750, while the first published literary text of a Slovenian woman author goes back only to 1848 (Moskal 2005, Mihurko Poniž 2014: 7). The Victorian period alone saw the publication of about 20,000 novels written by English women authors (Poster 1997: 3), and in the mid-19th century, M.A. Stodart's discussion introduced a scholarly approach to the content, context and form of so-called women's literature (Stodart 1842; Wilson 2009: 69). If the first women evaluators of novels by women authors were asking themselves about the simple characteristics of the "non-male" approach (in 1848 Elizabeth Eastlake doubted that the novel Jane Eyre was written by a woman, in 1856 George Eliot warned that an exaggerated female style may appear silly), the comparative study by Margaret Oliphant's Literature of the Last Fifty Years produced the first canonization of women authors as early as in 1887 (Rigby 2003; Eliot 2003; Oliphant 1996; Wilson 2009: 62, 67).While nowadays at the university level, the Anglo-Saxon literary world studies the texts of canonized as well as noncanonized women authors (Poster 1997), Slovenia still indulges in intensive debates as to which women authors can be classified in the national literary canon at all. The last decade has featured three fundamental texts that form the scholarly basis for the canonization of some Slovenian women authors. These are the monographs by Katja Mihurko Poniž Labirinti ljubezni v slovenski književnosti od romantike do II. svetovne vojne (Labyrinths of Love in Slovenian literature from Romanticism to World War II, 2008), Evine hčere: konstruiranje ženskosti v slovenskem javnem diskurzu 1848-1902 (Eve's Daughters: Constructions of Womanhood in Slovenian Public Discourse 1848-1902, 2009) and Zapisano $z$ njenim peresom: prelomi zgodnjih slovenskih književnic s paradigmo nacionalne literature (Written with Her Pen: Early Slovenian Women Authors' Break with the Paradigm of National Literature 2014).

Mihurko concludes that "the first rank of Slovenian $19^{\text {th }}$ century and early $20^{\text {th }}$ century authors (with the possible exception of Zofka Kveder) contains no women authors" and that the $19^{\text {th }}$ century substantive condition for a literary work to succeed was "its national character, reflected primarily in the positive (male!) proponent of Slovenian nationality". In contrast to male writers, Slovenian women authors, "due to insufficient links to the national literature, followed the example of women predecessors or contemporary women authors belonging to foreign literatures, these examples being however heavily criticized, even ridiculed" (Mihurko Poniž 2014: 6-9). The authors of literary-historical studies and reviews derived from traditional views of gender roles in the society and their judgments influenced the formation of the literary canon and consequently the exclusion of women authors. With her detailed comparative analysis, Katja Mihurko Poniž attempted to evaluate all that was "different, innovative in the works of early Slovenian women writers and thus indicated a breaking point from the Slovenian (male) literary tradition" (Mihurko Poniž 2014: 10-11). ${ }^{2}$ Mihurko's research

\footnotetext{
${ }^{2}$ This refers to the introduction of gender identity as a factor in the building of national identity, to innovation in the sentimental pattern, to a shift in depicting motherly characters as central figures, to the literary space as a factor in the emancipation process and to the new woman character creation as the meeting point of modern views of woman's role.
} 
findings attained wider validity and international confirmation within an international project, taking place from 2009 to 2013 under the title COST Women Writers in History.

\section{Slovenian Secondary School Literature Textbooks: Empirical Research}

The first part of my doctoral dissertation comprised an extensive study I carried out on Slovenian secondary school literature textbooks, dating from the March Revolution in 1848 to the beginning of the $21^{\text {st }}$ century, a period spanning a century and a half. It was published in monograph form, titled Slovenska literatura $v$ šoli in Prešeren (Slovenian literature in school and Prešeren, Božič 2010: 21-357). I examined literary, cultural, historical and instructional aspects of Slovenian literature textbooks, both those from national and ethnic Slovenian territory as well as those produced for Slovenian emigrant communities, published during the Austro-Hungarian Monarchy, the interwar period, during World War II, in post-war federal Yugoslavia and in independent Slovenia after 1991. I analyzed 56 series of literature textbooks containing a total of about 200 volumes for individual years, divided into those for lower and those for upper secondary school.

As part of the research, I also analyzed the occurrence of Slovenian women authors relative to male authors, attempting an examination of the selection mechanisms that have influenced the share of women authors in literature textbooks and consequently the forming of the national literary canon.

\section{Gender and Social Origin of Slovenian Authors}

It would of course be completely senseless and provocative to claim that Prešeren was the first author of the school literary canon because he was male. However, the research question can be worded differently: would Prešeren have had absolutely equal prospects of canonization had he been a woman, or (if the question is generalized) do women have equal opportunities with men? The answer can be but an attempt at a partial clarification of this complex yet an important question, especially since female literary creators were very few in number due to extremely limited access to higher education throughout the 19 th century and partly also in the first half of the $20^{\text {th }}$ century. ${ }^{3}$

\footnotetext{
${ }^{3}$ The intractable problem faced by women who wanted to reconcile their higher education with their gender-determined traditional social roles can also be seen in journalist texts at the turn of the century: "At the turn of the $19^{\text {th }}$ to the 20th century a new view of femininity tries to convince us that an educated woman is capable and eager to take care of her children and her household, and to be exactly the wife her husband wishes, on top of her profession. Women authors write in this way to alleviate the fear of the 'modern woman' and prevent putting barriers in the way of their professional education." (Mihurko Poniž 2009: 9) These problems have remained very topical to this day.
} 
With regard to social background, $19^{\text {th }}$ century Slovenian poets and writers were generally educated farmers' sons, ${ }^{4}$ with the majority of them also being priests, while Luiza Pesjak, Josipina Toman-Turnograjska and Pavlina Pajk were able to become authors only because they were not of peasant origin. Until the end of World War II, Slovenian women poets and writers could not achieve the critical mass that would provide a complete interaction of canonization factors. Irrespective of this, in his discussion Ne, na parnas pa že ne (No, not a chance of ascending Mt. Parnassus), when comparing the possibilities of canonization of the author Pavlina Pajk and the naturalist author Fran Govekar, Miran Hladnik establishes that, together with the already mentioned reasons relating to country, family, and generation, "her gender was also fatal" for the exclusion of Pajk from the canon corpus (Hladnik 2001: 130).

\section{Women Authors in Slovenian Secondary School Literature Textbooks}

There are a total of 755 Slovenian authors in the series of textbooks from 1850 to 2010 , of which 64 are women authors, i.e. $8.5 \% .^{5}$ The fact that women authors do not have the same possibilities of canonization as male authors in Slovenian secondary school textbooks is evidenced in the table classifying Slovenian authors according to the number of their texts in literature textbooks and including only those with 10 texts and more. ${ }^{6}$ The list contains 137 authors, of which only five are women authors ${ }^{7}(3.6 \%)$, which means the original share was halved. ${ }^{8}$ Even more telling is the table of Slovenian authors by the shares of realized in comparison to potential classifications. Among women authors, the highest share (three-fifths) is held by Svetlana Makarovič, ${ }^{9}$

\footnotetext{
${ }^{4}$ A decade ago in the Le coin de table magazine, Antonija Bernard concluded that French literature has no authors of such background at all (Hladnik 2001: 128). Something similar can be assumed for English and German literatures. We are all too little aware that $19^{\text {th }}$ century Slovenian literature (when Slovenians have no proper ruling class nor their own state) is highly specific due to the rural origin of literary creators and that this fact is undoubtedly reflected in substantive and stylistic characteristics of Slovenian literary works.

${ }^{5}$ We cannot judge whether this is a lot or a little, since the comparison would require an appropriate ratio per gender for all Slovenian writers until today. To illustrate, I refer to data that the modern three-volume Antologija slovenskih pesnic (The Anthology of Slovenian Woman Poets, which covers a century and a half of continuous writing and publishing (the same time span as the secondary-school literature textbooks), includes 127 women poets with 677 poems (Novak Popov 2003-2007). Otherwise the "share of women poets in most general poetry anthologies reaches from 4 to 10 per cent", and has increased slightly recently (Novak Popov 2008: 115).

${ }^{6}$ Of these 64 women authors, as many as 46 (more than two thirds) had only one or two texts presented.

These are Zofka Kveder (20 texts), Vida Jeraj (19 texts), Luiza Pesjak (13 texts), Svetlana Makarovič (12 texts) and Ilka Vašte (11 texts).

${ }^{8}$ There is not a single woman in the first third of Table 1.

9 "A paramount exception, confirming the rule, is Svetlana Makarovič: she figures in all literary histories, anthologies, textbooks, she is the recipient of the most prestigious literary awards (Prešeren Fund, Jenko and Prešeren awards) and the only modern Slovenian woman author that will be presented in an American reference publication Dictionary of Literary
} 
who is thus comparable to authors such as Pavle Zidar, Anton Ingolič, Janez Svetokriški, Fran K. Meško, Andrej Hieng, Juš Kozak and Beno Zupančič, i.e. male authors of the second rank. Zofka Kveder, Berta Bojetu ${ }^{10}$ and Vida Jeraj hold a two-fifths share (similar to Marko Kravos, Franjo Maselj, Silvin Sardenko, etc.), while Luiza Pesjak, Vida Taufer, Mira Mihelič, Saša Vegri, Vida Brest, Pavlina Pajk and Josipina Toman have less than a quarter of potential classifications that were realized. ${ }^{11}$

An additional indicator showing the "canonizability" of women authors is the number of their literary texts in textbooks and their relation to other canon authors. Only 7 out of 56 series of textbooks place women writers among the first twenty authors (Table 1).

Table 1. The Rankings of Women Authors in Secondary School Literature Textbooks (among the first 20 authors)

\begin{tabular}{|l|l|c|l|l|c|}
\hline Series & $\begin{array}{l}\text { Woman } \\
\text { Author }\end{array}$ & Rank & Series & $\begin{array}{l}\text { Woman } \\
\text { Author }\end{array}$ & Rank \\
\hline Janežič 1867 & L. Pesjak & 17 & Zablatnik 1976 & M. Hartman & 19 \\
\hline Sket 1893N & L. Pesjak & 8 & Inzko 1985 & M. Hartman & 2 \\
\hline Wester 1922 & V. Jeraj & 18 & Krakar 2003 & S. Makarovič & 19 \\
\hline Smolej 1946 & M. Drnovšek & 16 & & & \\
\hline
\end{tabular}

As can be seen in those rare series where they were admitted to the male elite, women authors generally rank in the lower part of the scale. ${ }^{12}$ There are exceptions: the eighth place ranking of Pesjak in Sket's textbooks for lower secondary schools ${ }^{13}$ (however, Pesjak falls out of the first twenty in the new editions of these textbooks) and the second position of Hartman in Inzk's series for the lower grammar school, which can be explained through favouring the native woman poet. ${ }^{14}$

The representation of women authors in literature textbooks after Slovenia's independence has been analyzed several times recently (for example, Sobočan 2008: 107-109; Novak Popov 2008: 116); nevertheless,

Biographies" (Novak Popov 2008: 116). Novak assumes that "her unanimous acclaim is not without connection to the militancy, belligerence, sharpness and strength with which the woman characters of her narrative poems overcome disillusion, hostility, isolation and homelessness, as well as the attitude of modernism in a universal, abstract subject matter".

${ }^{10}$ Berta Bojetu only has two published texts, since she first appeared in the Krakar 2003 series.

11 Revelatory is also the ratio between an author's birth year and the year of her first publication in a textbook. According to this ratio almost all five women authors with more than ten publications are classified in the second part or the table (only Vida Jeraj has $39^{\text {th }}$ ranking), in other words, this ratio spans from 35 to 48 years.

${ }^{12}$ Five out of seven series of textbooks are intended for the lower secondary school and only two for the upper secondary/secondary school.

${ }^{13}$ The relatively high position of Luiza Pesjak may be attributable to her connection to Prešeren.

${ }^{14}$ Different emphases appear in anthologies of Slovenian poetry. Women poets were classified among the first twenty authors in three out of seven anthologies: the Ilešič 1906 anthology even has two of them, namely Ljudmila Poljanec in twelfth place and Vida Jeraj in twentieth. Golar's 1920 anthology puts Poljanec at ninth place, while Bajt's 1993 anthology gives Svetlana Makarovič the eighteenth place. 
only a historical examination of relations between men and women can reveal classification and canonization factors. ${ }^{15}$ In Table 2 I refer to the series of textbooks which have the highest number of women authors (ten and more) and the series without any women authors, together with the number of all Slovenian authors and the number of original Slovenian texts in those textbooks (Table 2). ${ }^{16}$

Table 2. The Highest and the Lowest Number of Women Authors in Secondary School Literature Textbooks

\begin{tabular}{|l|c|c|c|l|c|c|c|}
\hline Series & All & Women & Texts & Series & All & Women & Texts \\
\hline Gaspari 1940 & 144 & 10 & 399 & Brinar 1912 & 76 & 0 & 285 \\
\hline Boršnik 1947 & 97 & 15 & 283 & Brinar 1923 & 78 & 0 & 300 \\
\hline Jamar 1956 & 96 & 15 & 460 & Smolej 1945 & 24 & 0 & 49 \\
\hline Bratuž 1982 & 121 & 10 & 551 & Čekuta 1947 & 50 & 0 & 130 \\
\hline Inzko 1985 & 115 & 11 & 286 & Beličič 1947 & 50 & 0 & 180 \\
\hline Bratuž 1994 & 180 & 12 & 735 & Gregorač 1979 & 70 & 0 & 221 \\
\hline Krakar 2003 & 157 & 14 & 411 & Fatur 1990 & 29 & 0 & 43 \\
\hline Total & $\mathbf{9 1 0}$ & $\mathbf{8 7}$ & $\mathbf{3 1 2 5}$ & Total & $\mathbf{3 7 7}$ & $\mathbf{0}$ & $\mathbf{1 2 0 8}$ \\
\hline
\end{tabular}

The basic finding is that women authors are more likely to be included in secondary school series of textbooks if the scope of these textbooks is greater (about a hundred or more Slovenian authors and about three hundred or more original Slovenian texts), and much less likely in a smaller size series (under eighty Slovenian authors and less than three hundred original Slovenian texts). This relationship is, however, not proportional, as in the series of textbooks on the right side of the table about thirty women authors should be expected (on average four women authors per series). The fact is that below a certain critical mass of authors and texts (with a stricter canonization selection) women authors simply disappear. The highest share achieved by women authors was in textbooks for lower secondary school grades immediately after the Second World War (about 15\%), ${ }^{17}$ while among textbooks for the upper secondary school the primacy is held by the modern 2003 Krakar series (about 9\%). ${ }^{18}$

\footnotetext{
${ }^{15}$ Ana M. Sobočan writes: "Branja (Readings) offer an exceptional richness of women authors and texts, so far unprecedented." Boršnik's 1947 series for lower secondary schools even had one additional Slovenian women author, while Bratuž's 1994 series for upper secondary schools had only two fewer women authors.

$1619^{\text {th }}$ century series of textbooks are deliberately omitted as women authors were disproportionately few then.

${ }^{17}$ This must be undoubtedly connected with efforts for social affirmation of women between the two wars and with a different attitude to the female gender by the winners of World War II.

18 "Without taking heed of obligatory and mandatory elective authors/texts, we smuggled women poets Lili Novy, Pavla Medvešček, Katja Špur (Branja 3) and Saša Vegri, Svetlana Makarovič, Maja Haderlap, Maja Vidmar, Pavla Gruden and Milena Šoukal (Branja 4) into the new literature textbook for general and 4-year technical grammar schools" (Novak Popov 2008: 116).
} 


\section{The Impact of the Textbook Editor's Gender on the Presentation of Women Authors}

Table 2 indicates that the editor's gender is an important selection factor (another being the volume), ${ }^{19}$ since except for Vera Gregorac ${ }^{20}$ all series on the right side have been edited by men, while, with the exception of two series (Gaspari 1940, Inzko 1985), the series of textbooks on the left side have been edited by women. To shed more light on this factor, Table 3 presents another three series on each side, a series with large volumes and a low number of women authors on the left side and three modern competing series on the right side.

Table 3. Women Authors in Large Volume Literature Textbooks and in Modern Ones

\begin{tabular}{|l|c|c|c|l|c|c|c|}
\hline Series & All & Women & Texts & Series & All & Women & Texts \\
\hline Grafenauer 1930 & 110 & 3 & 567 & Kos 2003 & 107 & 4 & 199 \\
\hline Merhar 1951 & 98 & 3 & 439 & Krakar 2003 & 157 & 14 & 411 \\
\hline Bohanec 1975 & 112 & 5 & 488 & Lah 2010 & 76 & 5 & 165 \\
\hline
\end{tabular}

Grafenauer's, Merhar's and Bohanec's series of textbooks for upper secondary/secondary school were edited in various periods. What makes them very similar are their volumes and very low shares of women authors (3 to 4\%). The first and the last series were prepared by men only, while the Merhar 1951 series is the work of four men and two women. It is to be expected of contemporary series that given the more modest scope of Kos's 2003 series of textbooks it contains fewer women authors than Krakar's 2003 series (although not that many fewer, as the volume of textbooks is not three times smaller). The comparable Lah 2010 series of textbooks, which features texts strictly linked to the curricular authors, ${ }^{21}$ has a higher number of women authors in spite of a smaller volume. In this case, the editor's gender is undoubtedly an important selecting factor, since the editors of Kos's textbooks are mostly men, while there is a strong prevalence of women in concurrent series. ${ }^{22}$

\footnotetext{
${ }^{19}$ Women first appear as editors of secondary school literature textbooks after World War II, and they first establish themselves in lower secondary school textbooks. A similar process can be detected in cross-border ethnic Slovenian territories (with the exception of Austrian Carinthia). Males dominate secondary school textbooks (after 1958) until 2000 (with the exception of Gregorač 1979 and 1980 as well as the Gorjup 1979 series). The authors of modern series are mostly women (such as the Krakar 2003 and Lah 2010 series), only Kos 2003 shows male dominance, while women are responsible for the instructional tools, a less appreciated part of the textbook.

${ }^{20}$ The Gregorač 1980 series, with its smaller scope than the series for secondary economy schools, has only one woman author.

${ }^{21}$ The Kos 2003 series has more authors and texts than the Lah 2010 series mainly because of the text fragments added.

${ }^{22}$ Modern series as well confirm the thesis that a smaller scope of the literature textbook decreases the likelihood of women authors being included.
} 


\section{A Comparison of the Share and Selection of Women Authors in Slovenian Literary History}

At the end of this problem set, let me provide a comparison with the selection criteria and actual choices of women authors in one of the Slovenian literary histories. ${ }^{23}$ In principle, the works of literary history may present a higher number of women authors than school textbooks which have, due to the publications of literary texts or their excerpts, a substantially smaller volume and thus a much stricter selection of nationally significant writers. This literary history is special particularly because of the separate presentation of top writers and their literary works. Table 4 presents literary periods and the number of all canonized authors and the number of women authors.

Table 4. Canonized Women Authors in Slovenian Literary History

\begin{tabular}{|l|c|c|}
\hline Period & All & Women \\
\hline Reformation and Counter-Reformation, Mannerism and Baroque & 35 & 0 \\
\hline Classicism and Pre-Romanticism & 14 & 0 \\
\hline Classicism and Romanticism & 17 & 1 \\
\hline Realism & 21 & 0 \\
\hline New Romanticism and two borderline forms of Realism & 39 & 4 \\
\hline Expressionism and Social Realism & \\
\hline Existentialism and Structuralism & 72 & 4 \\
\hline Total & 25 & 1 \\
\hline
\end{tabular}

In this case, too, there is disproportional representation, and the share of canonized women authors equals the level of women authors who are among those important writers with ten and more publications (4\%) in secondary school literature textbooks. The canonized women writers in this literary history are Josipina Toman, Ljudmila Poljanec, Vida Jeraj, Zofka Kveder, Lea Fatur, Lili Novy, Milena Mohorič, Erna Muser, Mira Mihelič and Saša Vegri. Out of five women authors represented in textbooks with ten and more texts, only Zofka Kveder and Vida Jeraj are among these ten authors above, and among the five women authors appearing within the first twenty authors in individual secondary school series of textbooks, from these ten authors only Vida Jeraj is of literary historical impact. This means that for the female gender literary historical canonization and secondary school canonization can also differ substantially.

\footnotetext{
${ }^{23}$ My choice of Pogačnik's and Zadravec's Zgodovina slovenskega slovstva (The History of Slovenian Literature, 1968-1972) in eight volumes was deliberate, as it has very clearly defined canon authors (articles in the chapters Beseda in ustvarjalec - Word and creator).

${ }^{24}$ This period appears in two volumes.
} 


\section{Women Authors in Mother Tongue Classes in Modern Slovenian Grammar School}

As already mentioned, among three competing textbooks for general and technical grammar schools the series of textbooks Branja 1-4 (Readings 1-4), prepared for the DZS publishing house by Slovenian educator Boža Krakar Vogel and her colleagues, stands out for its share of women authors. However, in the current grammar school curriculum, dating from 2008, which divides the included literary texts into obligatory, mandatory elective and freely elective texts, women authors appear only in the last two sets of prescribed readings. As the lists of obligatory home readings do not contain a single woman author, this means that the decision as to whether students will get to know any Slovenian women authors depends entirely on the individual Slovenian language teacher.

A similar condition is in the selection of titles for annual topical sets for writing the annual argumentative and interpretative matura essays, where comparable texts written by domestic and foreign authors have been appearing for twenty years (in recent years usually two novels or four theatre pieces have been selected). The selections over the last two decades have included only two foreign women authors, namely Jane Austen's novel Pride and Prejudice and Nathalie Sarraute's novel Childhood, and no Slovenian women authors.

\section{Conclusion}

Based on the results of an empirical study it can be concluded that in Slovenian secondary school literature textbook women authors are in fact the second and in this case neglected and the inferior gender, due mainly to the fact that the top national literature, at least until World War II, was represented predominantly by men, and that textbook editors up until 1945 were solely men. Even after that they were accompanied by women whose attitude towards literature and its role in the school system was identical to men's views.

Not only in the name of gender equality, but also due to the simple fact that women's literature in its difference can be equal in value and quality, a reevaluation of Slovenian literary history is crucial, resulting in the inclusion of a higher number of native and foreign women authors in Slovenian secondary school literature textbooks. It would not, however, be wise to introduce any abrupt changes; on the contrary, we should take a careful interdisciplinary approach, which would first, by connecting the modern approaches of literary studies and the didactics of literature, verify the reception of competitive texts by male and female authors from a particular period of literary history. 


\section{Bibliography}

Božič Z (2010) Slovenska literatura $v$ šoli in Prešeren (Slovenian literature in school and Preseren). Ljubljana: Založba Tangram.

Eliot G (2003) Silly Novels by Lady Novelists. A Serious Occupation: Literary Criticism by Victorian Women Writers. Eds. Solveig C. Robinson. Peterborough, Ontario: Broadview, p. 113.

Hladnik M (2001) Ne, na parnas pa že ne! (No, Parnassus already do!), Proceedings of the $37^{\text {th }}$ Seminar of the Slovenian language, literature and culture. Edited by Irena Orel. Ljubljana: Center za slovenščino kot drugi/tuji jezik, pp. 115-138.

Lynn Budin S, MacIntosh Turfa J (ed.) (2016) Women in Antiquity: Real Women Across the Ancient World. London and New York: Routledge.

Mihurko Poniž K (2008) Labirinti ljubezni v slovenski književnosti od romantike do II. svetovne vojne. (Labyrinths of love in Slovenian literature from romanticism to II. world war). Ljubljana: Založba Sophia.

Mihurko Poniž K (2009) Evine hčere: konstruiranje ženskosti v slovenskem javnem diskurzu 1848-1902 (Eve's daughters: the construction of femininity in the Slovenian public discourse 1848-1902). Nova Gorica: Založba UNG (University of Primorska Press).

Mihurko Poniž K (2014) Zapoisano z njenim peresom: prelomi zgodnjih slovenskih književnic s paradigmo nacionalne literature (Zapoisano with her pen: breaks early Slovenian writer with the paradigm of national literature). Nova Gorica: Založba UNG.

Milek V (2016) Drogo lahko prodaš samo enkrat, deklico večkrat (A drug can be sold only once, a girl several times - an interview with the president of PEN International, Jennifer Clement). Delo 58 (Sobotna priloga), 14th May 2016.

Moskal J (2005) Introduction. Teaching British Women Writers, 1750-1900. Eds. J Moskal, SR Wooden. New York: Peter Lang. 2.

Novak Popov I (2003-2007) Antologija slovenskih pesnic 1-3 (Anthology of Slovenian poets 1-3). Ljubljana: Tuma.

Novak Popov I (2008) Slovenske pesnice v literarni vedi in izobraževanju (Slovenian poets in literary criticism and education). Književnost v izobraževanju - cilji, vsebine, metode (Obdobja 25). Eds. Krakar Vogel, Boža. Ljubljana: Filozofska fakulteta. 113-128.

Oliphant M (1996) The Literature of the Last Fifty Years. Prose by Victorian Women. Eds. Andrea Broomfield, Sally Mitchell. New York: Garland Publications, pp. 487-504.

Poster C (1997) Canonicity and the Campus Bookstore: Teaching Victorian Women Writers. Feminist Teacher 11(1): 1-9.

Rigby (Eastlake) E (2003) Review of Vanity Fair and Jane Eyre. A Serious Occupation: Literary Criticism by Victorian Women Writers. Eds. Solveig C. Robinson. Peterborough, Ontario: Broadview, p. 73.

Sobočan AM (2008) Branje kanona (Reading canon). Književnost v izobraževanju cilji, vsebine, metode (Obdobja 25). Ed. Krakar Vogel, Boža. Ljubljana: Filozofska fakulteta. 99-112.

Stodart MA (1842) Female Writers, Thoughts on Their Proper Sphere and on Their Powers of Usefulness. London: R. B. Seeley and W. Burnside.

Wilson CA (2009) Placing the Margins: Literary Reviews, Pedagogical Practices, and the Canon of Victorian Women's Writing. Tulsa Studies in Women's Literature 28(1): 57-74. 
